\title{
The Genetics, Biochemistry, and Biophysics of Carbon Cycling by Deep Life
}

\author{
KAREN G. LLOYD, CODY S. SHEIK, BERTRAND GARCÍA-MORENO, AND \\ CATHERINE A. ROYER
}

\subsection{Introduction}

Much of the microbial life on Earth resides below the surface in the crust (Figure 18.1) (1), either buried in marine sediments (2) and petroleum deposits (3) or entrained in aquifers within oceanic and terrestrial rocks (Figure 18.2) (4-8), fluid inclusions in salt, permafrost, and ice (9-11), as well as hydrothermal and geothermal fluids (12,13). The study of deep subsurface life has defined our understanding of habitability and expanded our knowledge of the mechanisms that enables life to live in these environments (14). While the study of deep life may seem like a philosophical exercise, understanding this enigmatic biosphere has important real-world implications for assessing the safety and feasibility of underground storage of spent nuclear fuel and other toxic compounds, sequestration of atmospheric $\mathrm{CO}_{2}$, or acquisition of fuels such as tar sands, deep subsurface coal beds, methane hydrates, or fracking $(3,5,15)$.

Organisms inhabiting subsurface environments likely have been isolated from the surface world for hundreds to millions of years (16). Thus, their metabolic lifestyles may differ substantially from those of surface organisms. Even though subsurface environments are diverse (Chapter 16, this volume), subsurface microbes share common biological challenges such as limitations of energy, resources, and space, as well as extremes of pressure, $\mathrm{pH}$, osmolarity, and temperature (Chapter 17, this volume). On the other hand, subsurface environments offer biological advantages, too: environmental stability, protection from UV irradiation, and oxygen. These unique subsurface conditions lead to communities that are often phylogenetically and functionally diverse, with extremely slow population turnover times $(14,17,18)$ and efficient energy metabolisms $(14,19)$. Increasingly, the roles of viruses and eukaryotes, in addition to bacteria and archaea, are being recognized in the deep subsurface biosphere (20-25). Several barriers hamper the study of life in Earth's crust, such as sample acquisition and the difficulty of retrieving sterile, unaltered samples that have not been contaminated by drilling fluid. However, an even bigger hurdle is the difficulty of studying the copious subsurface microbes with no cultured representatives $(13,26)$. Their functional potential must be pieced together from direct assessments of biomolecules or biochemical processes in natural samples. However, even subsurface microbes related to laboratory cultures with "known" functions, may not perform those functions in the natural 


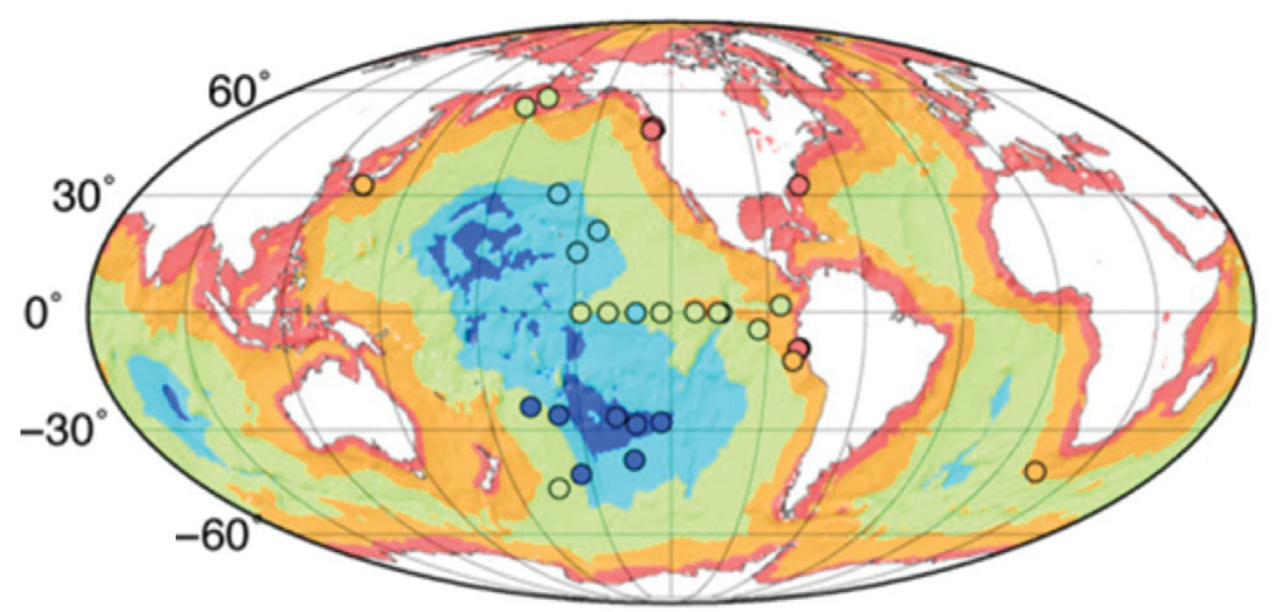

Cell Count $\left(\log _{10}\right.$ cells $\left.\mathrm{km}-2\right)$

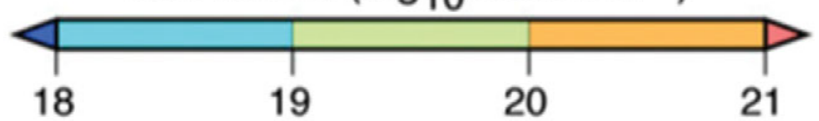

Figure 18.1 Global distribution of marine sediment densities of microbial cells, integrated with depth (adapted from 1).

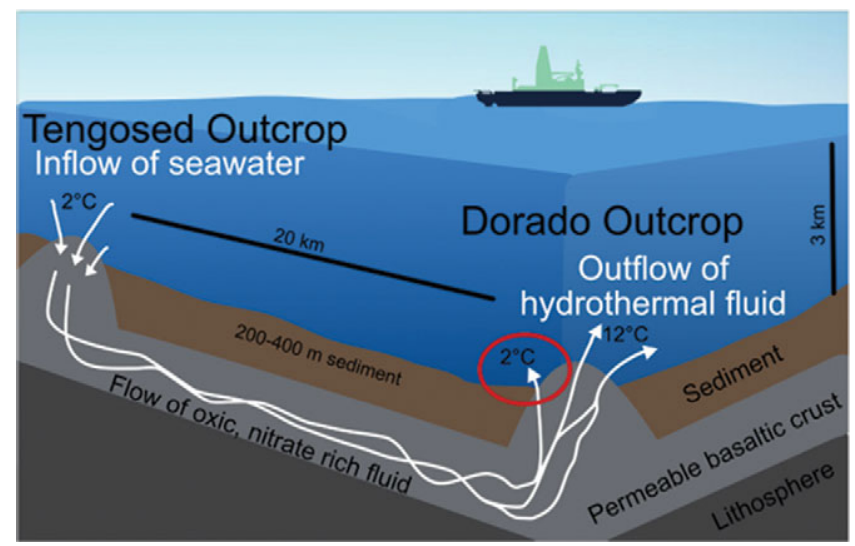

Figure 18.2 Example schematic of a deep subsurface basaltic aquifer. Such environments provide a substantially different habitat for microbial life from sediments or soils (adapted from 33).

environment. Nonetheless, culturing has been extremely important in establishing the existence of a living deep subsurface biosphere (27-32). Researchers must therefore combine direct molecular biological assessments with geochemical and geophysical environmental parameters to describe how carbon is microbially transformed in subsurface environments. 


\subsection{Genetic Potential of Subsurface Environments}

Much research addresses the question of how subsurface life differs from surface life in genetics, biochemistry, and biophysics. Culturing-based methods are still the cornerstone of microbiology because they enable physiological assessments in carefully controlled experiments. However, it is universally accepted that culturing-based methods typically recover a very small proportion of the total microbes from any environment (34-36). Our inability to cultivate microbes is a multifaceted problem that in part has been driven by our inability to perfectly recreate the physical and chemical conditions necessary for growth, slow microbial growth rates, and the rise in popularity of molecular techniques that produce data rapidly. Thus, like the rock record, our views of microbial life and the processes they perform in situ are incomplete. While this may seem bleak, there is renewed interest in the cultivation and development of novel culturing techniques, such as high-pressure culture vessels, and this is being spurred, in part, by discoveries made through genome sequencing.

Ribosomal gene sequencing has revolutionized our understanding of the microbial evolution and diversity of microbial phyla (37-39). These culture-independent methods have been a boon for the study of subsurface life, as many of the organisms in the subsurface require direct environmental sequencing because they are slow growing (40), potentially dormant $(41,42)$, or require specific growth conditions or partners (43). Singlegene amplicon sequencing (i.e. 16S rRNA or nitrate reduction genes) remains the most used method for assessing microbial communities, but it lacks the resolution to decipher the metabolic potential of the microbes observed. However, other popular sequencingbased methods can also indicate metabolism, like single-cell amplified genomes (SAGs) or metagenomics and metatranscriptomics, where total community DNA and RNA are sequenced directly from environmental samples $(4,44,45)$. The Census of Deep Life (https://vamps2.mbl.edu/portals/CODL), within the Deep Carbon Observatory, has enabled DNA sequencing from many deep subsurface environments and will provide a great resource as this work continues (46).

The main hurdle for the molecular-based analysis of subsurface environments is the amount of microbial biomass present in the sample, which is often low. Nucleic acid extraction from any environmental sample is a fundamental step for all molecular-based studies (Figure 18.3). Extraction methods are extremely diverse and highly dependent on the samples being processed. Recent work has highlighted that commercial DNA/RNA extraction kit reagents, typically designed for high-biomass environments, contain their own microbiome that can skew downstream amplicon data analyses $(46,47)$. It is also important to remove reagent contamination from SAGs, metagenomes, and metatranscriptomes (48-50). Thus, great care must be taken to screen resulting reads and assembled contigs to identify and remove suspicious sequences, while also allowing that sometimes organisms that were previously thought to represent surface contamination, such as cyanobacteria, may actually be legitimate community members (51).

Post-sequencing analysis of genomes, metagenomes, and metatranscriptomes has made significant advances that have greatly enhanced our knowledge of subsurface life (52-54). 


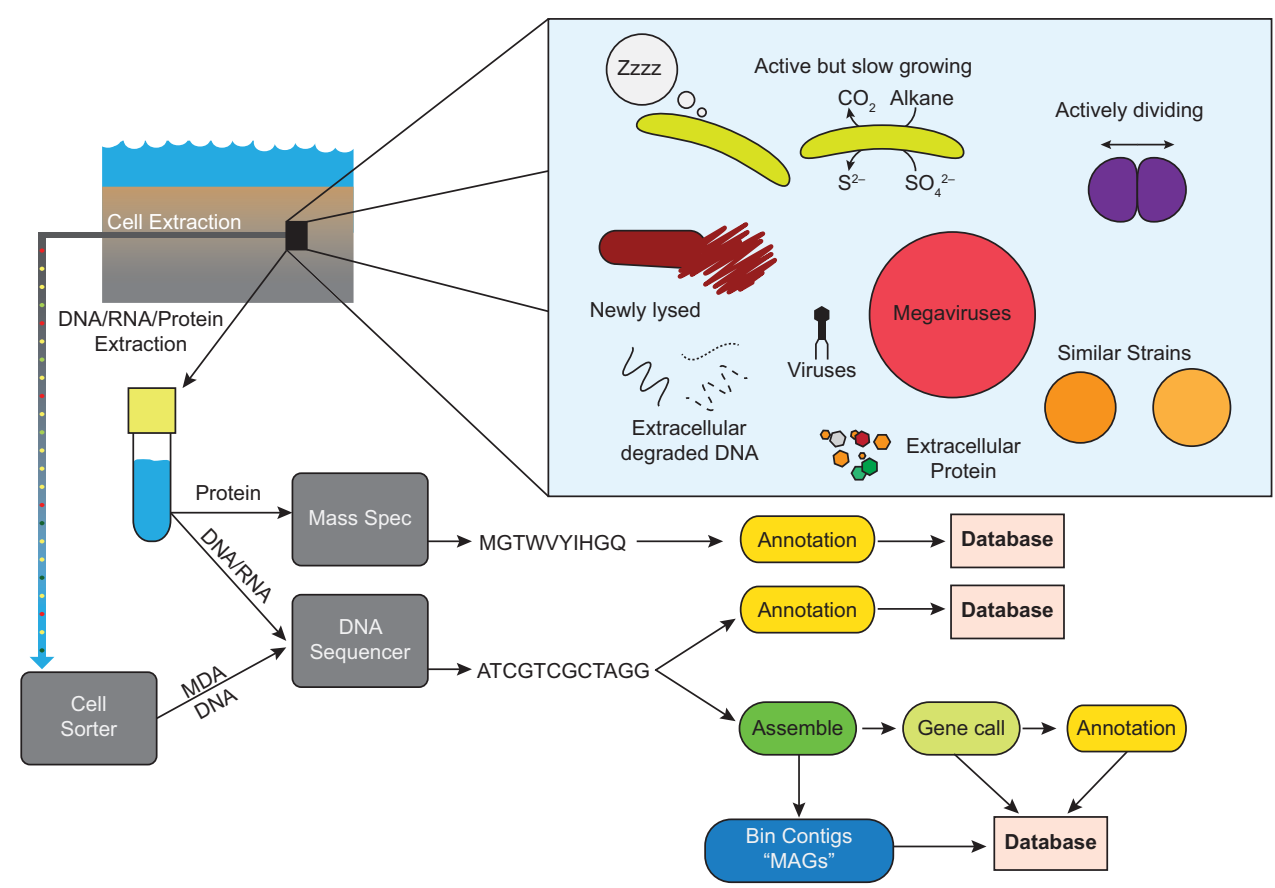

Figure 18.3 Schematic workflow for molecular studies of subsurface ecosystems. MAG = metagenome-assembled genome; MDA = multiple displacement amplification.

The ability to identify and extract microbial genomes from metagenomes (i.e. genome binning, also referred to as metagenome-assembled genomes (MAGs)) (55), along with SAGs, has enabled physiological inferences to be made for uncultured subsurface organisms. Recovery of genomes from metagenomes like Candidatus Desulforudis audaxviator (52) or Leptospirillium and Ferroplasma (56) revealed that microbes living in lowdiversity, subsurface environments contain a large amount of genomic diversity, strain heterogeneity, and physiological diversity. $C a$. D. audaxviator and $C a$. Desulfopertinax cowenii contain metabolic pathways for heterotrophic growth as well as the potential to fix carbon via the Wood-Ljungdahl (WL) pathway (57). In subsurface environments, the WL pathway has been increasingly identified in MAGs and SAGs. The presence of the WL pathway is intuitive as it requires minimal energy to fix $\mathrm{C}$ to biomass (58) and is reversible to oxidize acetate. Interestingly, energetically taxing pathways such as the Calvin-BensonBassham cycle are also present (4,59). Metagenome sequencing and subsequent genome binning have been applied to several subsurface environments, such as sediments (marine and freshwater), aquifers, rock, caves, mines, and marine basalts (4,60-68). In these systems, chemolithoautotrophy is always counterbalanced by heterotrophs and fermentative organisms $(4,61)$. As more subsurface environments are sampled and sequenced and their genomes assembled from metagenomes, researchers have the ability to apply 
pangenomic and phylogenomic approaches (69) to look for functional and evolutionary differences in subsurface populations. Jungbluth et al. (57) applied these techniques to show genomically that deep terrestrial subsurface $C a$. D. audaxviator lacks carbon uptake genes that the marine subsurface $\mathrm{Ca}$. D. cowenii has, indicating the potential for metabolic plasticity. SAGs have also been used to target and recover specific genomes of interest from the environment $(22,70,71)$. These targeted approaches provided insight into the carbon metabolism of two ubiquitous and enigmatic Archaea (72). However, as with metagenome sequencing, recovery of complete genomes can be difficult (48). Regardless of method, these tools have provided an unprecedented glimpse into the diversity - in terms of the number of both microbes and functional genes - of subsurface microbes, and they finally allow microbiologists to draw conclusions as to the functional interactions between microbes that drive system productivity $(4,60,64,66)$.

Metatranscriptomics provides a snapshot of the environmental conditions microbes sense at the time of sampling, as the turnover of RNA in the cell is rapid, being in the order of minutes for many microbes (73). Orsi et al. applied a metatranscriptomic-based approach to show that sub-seafloor sediment microbes express genes for carbohydrate and protein degradation pathways (45). Lau et al. (43) were able to construct metabolic interaction maps of microbial communities in a terrestrial subsurface South African gold mine. These microbial communities appear to use a diversity of carbon fixation and decomposition pathways to cycle carbon. De novo assembled metatranscriptomes can be a useful tool for looking at broad patterns of expression in the subsurface $(43,74)$ or the contribution of rare community members to biogeochemical cycles (75). However, this method is highly dependent on the annotation databases and thus could missannotate functions or be unable to give a phylogeny. Even with these caveats, metatranscriptomics coupled to either MAGs or SAGs can link potentially novel microbes to biogeochemical cycles.

Genes and gene transcripts do not always link directly to organismal activity due to post-transcriptional regulation of microbial functions (76). Therefore, proteomics may be a way to probe microbial functions of the entire community more directly. This method has only recently been applied to deep subsurface samples (43). Lau et al. showed that a wide variety of metabolic activities co-occurred at a 1.34-km deep fault zone, implying that the organisms acted syntrophically to support an autotrophic-based ecosystem (43). Proteomics and genomics also suggested metabolic interdependencies among subsurface microbes in an acetate-fed aquifer (77). Another method that pushes closer to measuring microbial activity in situ is metabolomics, which uses mass spectrometry to identify all of the small organic molecules present in a sample. This, too, has the potential to point to metabolic pathways that are functional in deep subsurface samples, but it has only recently come into use (78). The greatest challenge facing metabolomics is dealing with the large number of unknown structures in the data set - a problem shared with all complex microbial communities.

The rapid acceleration of data produced from genomic, transcriptomic, and soon proteomic and metabolomic research into deep subsurface environments has opened up a new dimension regarding how we learn about this difficult-to-culture biosphere. Currently, 
data production far outstrips the ability of a single research lab to analyze each data set to completion. This is already beginning to support a potentially rich research area of metaanalysis studies, where combining data sets from multiple studies allows for novel insights not apparent from a single data set alone (e.g. 46). Through further pushing of the boundaries of what can be achieved by applying biomolecular tools to environmental samples, there is no limit to what researchers can learn about this important biosphere. Such studies not only overcome some of the limitations of whole communities full of uncultured clades, but will also lead researchers to new approaches to achieve culturing of some of these recalcitrant growers.

\subsection{Biogeochemistry of Deep Subsurface Life}

Microbes are Earth's most prolific chemists. They do this by transforming organic and inorganic elements and compounds using enzymatic protein complexes. Earth's rock record provides a glimpse of some of these processes and their evolution over time, either through isotope signatures or mineral formations, with evidence for the coevolution of minerals and biology $(79,80)$. While the rock record provides a hint of what processes were in operation when they were deposited, interpreting these observations relies on the characterization of extant microbes.

Microbes transform the carbon landscape of Earth's subsurface largely by "eating" or "breathing" carbon-containing compounds (81). Respiring microbes use one molecule as an electron source (reductant) and another molecule as an electron sink (oxidant). Common reductants are organic molecules such as carbohydrates, amino acids, lipids, or small molecules like hydrocarbons, acetate, and formate, as well as inorganic compounds such as reduced sulfur, ammonium, transition metals, or $\mathrm{H}_{2}$. Carbon-containing oxidants include $\mathrm{CO}_{2}$ (in the case of methanogenesis), organic molecules like fumarate or oxalate, as well as inorganic compounds like $\mathrm{O}_{2}$, oxidized sulfur or nitrogen compounds, or oxidized transition metals. An alternative to respiration is fermentation, where microbes split a single molecule of intermediate oxidation state into a more oxidized one and a more reduced one. The reduced product often serves as the reductant for another organism's respiration. Organic matter is the most common fermentative substrate, but microbes can also ferment elemental sulfur through disproportionation. In addition to respiration and fermentation, which are primarily performed to give a microbe energy, microbes can also expend energy to take up carbon compounds. Most notably, primary producers incorporate $\mathrm{CO}_{2}$ to build biomass. Therefore, every type of microbe transforms carbon, and the presence of life on Earth has had profound effects on its carbon cycle.

To describe transformations of carbon compounds in deep subsurface environments, one must determine what combination of reductants, oxidants, and/or fermentative substrates are utilized, which microbial communities use them, and how quickly they do so (14). In many deep subsurface environments, highly oxidized oxidants such as oxygen and nitrate have already been consumed by shallow organisms, leaving the less powerful (per mole) oxidants such as sulfate and $\mathrm{CO}_{2}$ to dominate $(82,83)$. However, exceptions occur in 
environments with conduits connecting to surface-derived fluids such as deep basalts or surface-connected aquifers. In areas of the ocean floor with extremely slow sedimentation rates, $\mathrm{O}_{2}$ can be detected many meters deep into marine sediments $(33,84-86) . \mathrm{CO}_{2}$ fixation, usually powered by chemolithoautotrophy rather than photosynthesis, is a ubiquitous and important carbon transformation process in deep subsurface environments (87).

Through the application of novel biomolecular techniques that complement the DNA, RNA, and protein-based studies descried above, great strides have been made in the understanding of the biochemistry of microbes performing carbon transformation in Earth's subsurface. These methods include enzyme assays, lipid analysis, stable isotope probing (SIP), metabolomics of small metabolic intermediates, measuring or modeling respiration rates, and heterologous expression of novel enzymes from deep subsurface organisms.

\subsubsection{Microbial Metabolism in the Deep Subsurface}

Measuring the rate that a microbial function occurs is essential for determining how the function contributes to the carbon cycle. Older methods to study microbial activity in the deep biosphere, such as the incorporation of radioactive thymidine into bulk samples, have largely fallen out of favor since they are insufficiently sensitive to detect microbial activities below a few meters deep into sediments (88). A more sensitive method for estimating in situ microbial activity is to measure the turnover rate of trace amounts of radioactive nutrients such as electron donors/acceptors. Such methods have attained widespread use in subsurface environments and have shown that $\mathrm{SO}_{4}{ }^{2-}$ and $\mathrm{CO}_{2}$ serve as important electron acceptors for deep subsurface biosphere respiration (89). In agreement with this, DNA signatures for microbes capable of these types of respiration have been identified in many subsurface locations (e.g. 90,91). Although it may seem that better oxidants should correspond to faster organic matter degradation, recent work has suggested that the rate of carbon remineralization operates independently of which oxidant is available (92). Here, radiotracer-measured rates of carbon oxidation to $\mathrm{CO}_{2}$ were constant, whether sulfate or $\mathrm{CO}_{2}$ was the terminal electron acceptor.

Direct microscopic assessment is often uninformative about either taxonomy or physiology because cells tend to be small $(93,94)$ and their morphology does not indicate their identity or environmental functions (2). In recent years, SIP coupled to fluorescence in situ hybridization (FISH) and nanoscale secondary ion mass spectrometry (NanoSIMS) has enabled the direct metabolic assessment of natural populations incubated ex situ, but still within their natural microbial community. SIP works on the principle that organisms taking up isotopically labeled substrate will retain it in their biomolecules and can later be identified. After 9 and 405 days of seafloor incubation of a sediment core with ${ }^{13} \mathrm{C}$-labeled glucose, Takano et al. (95) found that subsurface archaea incorporate fresh glucose in the glycerol headgroups of their membrane lipids, but rely on detrital carbon recycling for the hydrocarbon isoprenoid groups of the lipids. FISH allows the microscopic identification of microbes of a particular taxonomic group by attaching fluorescent probes to short DNA 
sequences that match the taxonomically informative ribosomal RNA present in cells (96). In places with low activity, such as the deep subsurface, the dim fluorescence signals of FISH often require amplification with catalyzed reporter deposition (CARD) (97). NanoSIMS sputters a cesium ion beam across an area of a few micrometers to detect any isotopic label taken up by the microbe during the SIP incubation. Therefore, when combined with FISH, NanoSIMS SIP gives information about what substrates were consumed by which taxonomic groups of organisms on a nearly single-cell basis.

In 2011, Morono et al. used NanoSIMS SIP with CARD-FISH to show that cells in up to 460,000-year-old sediments, $200 \mathrm{~m}$ deep into the sub-seafloor, were capable of growing on glucose, pyruvate, and amino acids (98). In addition, acetate and bicarbonate were incorporated into the biomass, although they did not promote growth. However, whether the identity of the cells that grew in these experiments reflected the community present at the time of sampling was not assessed, since only a subset of the growing cells hybridized to FISH probes (98). This could be the result of either mismatches to the probe DNA sequences or difficulties of hybridizing cells during CARD-FISH $(99,100)$.

In one of the deepest sub-seafloor drilling operations to date, researchers on Integrated Ocean Drilling Program (IODP) Expedition 337 found relatively high numbers of microbial cells whose taxonomic identities resembled terrestrial communities in 2-km-deep coal beds, suggesting that these cells had persisted through the burial of these terrestrial sediments over tens of millions of years (101). By combining SIP, CARD-FISH, and NanoSIMS, Trembath-Reichert et al. found that these communities incorporated methylated compounds into the biomass, sometimes with concomitant methane production (102). Ijiri et al. combined clumped isotopic measurements and label turnover rates to show that deep fluids stimulate substantial methanogenesis at mud volcanoes (103).

An analogous method to SIP that allows single-cell analysis without requiring an expensive NanoSIMS instrument is called bio-orthogonal noncanonical amino acid tagging (BONCAT) (104). In this method, natural samples are incubated with an amino acid mimic equipped with a functional moiety that can react with a fluorophore after the incubation has ended. In this way, the microbial cells that were making new proteins (and therefore incorporated the amino acid mimic) fluoresce under a microscope and can be counted by eye or physically separated in a flow cytometer for downstream biomolecular study. BONCAT was used in subsurface samples to show stimulation of amino acid incorporation in microbial aggregates incubated with methane (105).

Metabolism can also be controlled by entering an inactive or dormant state. Among cultured bacteria, the Firmicutes and Actinobacteria are capable of forming endospores that can withstand low nutrients and inhospitable conditions for long time periods. These properties make sporulation a potentially advantageous phenomenon for deep subsurface life; however, it is possible that common DNA analyses miss spores since they can be difficult to lyse. Therefore, Lomstein et al. measured dipicolinic acid, a key spore coat protein, in the deep subsurface of the Peru Margin to estimate that spores in this deep subsurface environment may be as numerous as nonsporulated cells and the necromass from other dead cells that may provide food for metabolically active microbes (40). 
However, when the decrease in cellular biomass over sediment age is instead used to estimate the microbial necromass production rates, the rate is far outstripped by organic matter buried from ancient pelagic sedimentation (106).

In marine sediments with low organic matter contents and deep terrestrial aquifers, the radiolysis of water may provide microbial food. Natural radioactive decay of Earth's minerals can slowly split water into $\mathrm{H}_{2}$ and oxidized moieties (107). Hydrogen production from Earth's background radiation may seem inconsequential relative to the power provided by sunlight in surface environments. However, $\mathrm{H}_{2}$ production rates from water radiolysis have been shown to be sufficient to support life in the deep subsurface $(52,107,108)$. The deep subsurface may have additional sources of energy such as serpentinization, which produces the microbial substrate $\mathrm{H}_{2}$ and has been shown to support many microbial communities $(109,110)$. Serpentinization also produces a large amount of alkalinity, which inhibits autotrophy by pushing carbonate equilibrium away from $\mathrm{CO}_{2}$. Therefore, unique types of methanogens have been discovered in serpentinizing systems that have novel mechanisms for ameliorating $\mathrm{CO}_{2}$ limitation $(111,112)$.

A feature that may be very important to subsurface ecosystems is symbiotic relationships. Historically, microbial communities from deep subsurface aquifers have been studied by examining the cells that are caught on a $1.2-\mu \mathrm{m}$ filter, but recent work has shown that a wide range of ultrasmall bacteria pass through these filters (4). These cells form previously undiscovered branches on the tree of life called candidate phyla radiations (113). In addition to having extremely small cell sizes $\left(0.009 \pm 0.002 \mu \mathrm{m}^{3}\right)$, they have very small genome sizes as well, and they lack many features thought to be important to free-living organisms (4). In addition, their cell structures show that they have cellular appendages that might aid in cell-tocell communication, similar to those of ultrasmall uncultured archaea called archaeal Richmond Mine acidophilic nanoorganisms (ARMAN) (Figure 18.4) (94). Therefore, these candidate phyla radiations have been proposed to be obligate symbionts of larger microbes (4).

\subsubsection{Predicting Functions of Novel Genes}

Many of these genes in subsurface organisms cannot be accurately annotated by their homology to characterized gene products, since most of the latter come from microbes in pure culture (114). Given that genomic data are quickly becoming the most accessible type of data to shed light on deep biosphere communities (Section 18.2), the inability to interpret the functions of much of their genomes is a major limitation. For instance, from its genome and phylogeny, Desulfurivibrio sp. appear to be anaerobic sulfate reducers. However, when they were obtained in pure culture, they did not reduce sulfate, but instead oxidized it (115). A genome from an uncultured phylum contained a homolog of the methyl coenzyme $\mathrm{M}$ reductase gene, from which one might conclude that it performs methanogenesis or anaerobic methane oxidation. However, enrichments of this organism could not perform methane metabolisms, but instead oxidized butyrate anaerobically (116).

One method for overcoming difficulties in accurate annotations of genes in organisms that cannot undergo phenotypic ground-truthing is to amplify target genes of interest 


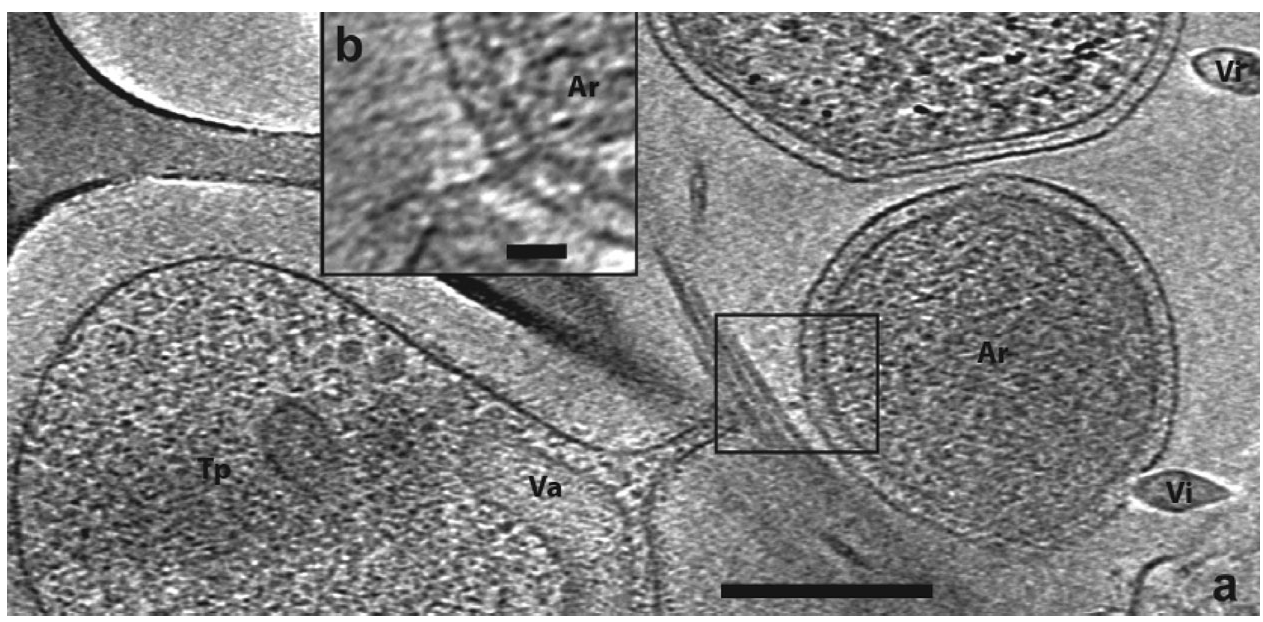

Figure 18.4 Cryo-electron tomographic reconstruction of ARMAN archaea (Ar), Thermoplasmatales (Tp), vacuole (Va), and virus (Vi). (a) shows the larger image, with a 300-nm scale bar, and (b) shows the inset, with a 50 -nm scale bar.

Image reproduced from (94).

directly from natural samples or single-cell genomes, ligate them into DNA plasmid vectors, transform them into Escherichia coli, express them as proteins, purify them, solve their structures, and characterize their activities. A predicted gene annotated as a peptidase in the uncultured phylum Bathyarchaeota was heterologously expressed in E. coli and crystallized in order to determine its structure and catalytic activity (117). Although the gene was annotated as an S15 peptidase with substrate specificity for terminal proline residues, the expressed enzyme, called bathyaminopeptidase, was found to have a much higher affinity for terminal cysteine residues. This distinction illustrates the limitation of inferring enzyme function from homology to known proteins in these uncultured deep subsurface microbes. Homologs of the gene for the II/III form of Rubisco, a well-studied key gene for $\mathrm{CO}_{2}$ fixation in the Calvin-Benson-Bassham cycle, occur in the candidate phyla radiation among the bacteria in deep terrestrial aquifers. This enzyme had previously only been found in cultured archaea, so its presence in uncultured phyla of deep subsurface bacteria suggested that perhaps it had different catalytic properties in these unknown groups $(4,118)$. However, adding the Rubisco II/III gene from the candidate phyla radiation lineage to a phototroph, Rhodobacter capsulatus, which had been engineered to remove its native Rubisco gene and had therefore lost its $\mathrm{CO}_{2}$ fixation capabilities (119), caused its full $\mathrm{CO}_{2}$ fixation capabilities to be revived (59).

The limitation of this heterologous gene expression approach is that it has much slower throughput than genetic characterizations. However, it provides hard evidence for function that is lacking when simply inferring enzymatic functions from homology to known proteins. In addition, it presents opportunities for discovering novel functions rather than making assumptions based on previously characterized proteins. 


\subsubsection{Cellular Bioenergetics}

Overcoming energy limitation is a major focus of life in both marine and terrestrial subsurface environments $(11,14)$. Reaction transport modeling of oxygen and nitrate concentration profiles with sediment age showed that deep subsurface communities in the South Pacific Gyre operate at extraordinarily low metabolic rates $(85,86)$. Subsurface microbes are therefore operating in a low energy state, and the majority of these populations may be in a long-term stationary stage in which they require energy only for cell maintenance $(120,121)$. Determining the minimum value for cellular maintenance is difficult, but nanocalorimetry, in which the kinetics and thermodynamics of very small populations of cells can be measured (122), and long incubations with no new substrate additions (123-125) hold promise for studying organisms operating at very low energies. At the very minimum, living cells must replace biomass fast enough to overcome abiotic racemization rates, which can be very slow $(126,127)$. Determining true growth rates for such natural microbial populations outside of carefully controlled laboratory conditions is nearly impossible because the change in the number of cells over time represents the product of growth rate minus death rate. However, total population turnover rates can be determined (14). Braun et al. used racemization rates to estimate total population turnover times of up to tens of years for marine sediment microbes in relatively organic-rich parts of the ocean (17). Slow biomass turnover times of several months to over 100 years have also been measured by measuring uptake of deuterated water (Figure 18.5) (102).

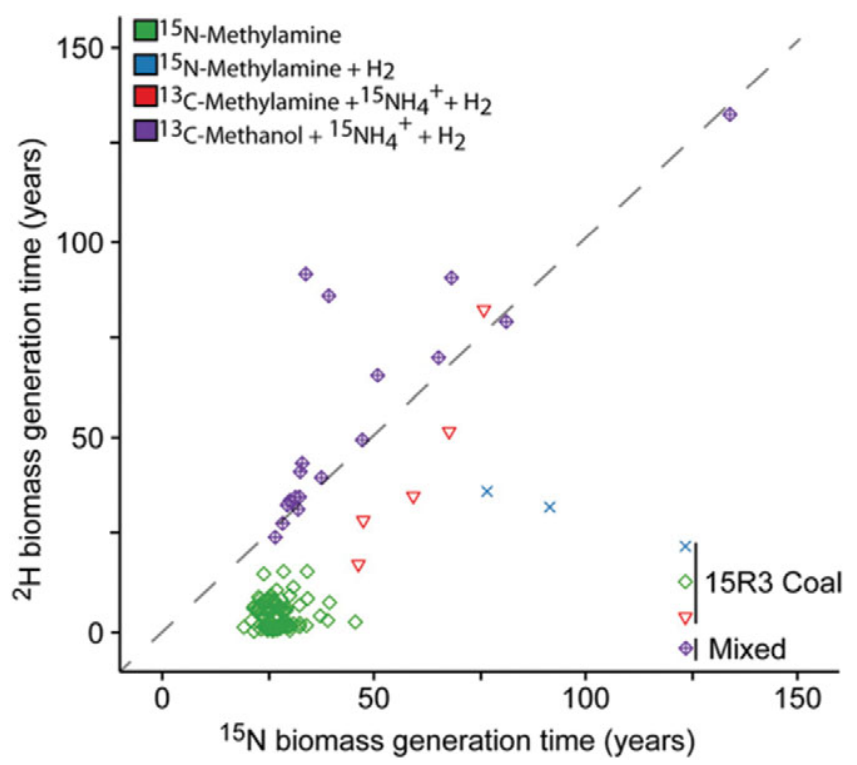

Figure 18.5 Generation times for microbial life in 2-km-deep sub-seafloor coal and shale beds based on uptake rate of either ${ }^{2} \mathrm{H}$-labeled water or ${ }^{15} \mathrm{~N}$-labeled compounds as described in the graph's key (adapted from 102). 
One challenge to such research is the difficulty in making accurate absolute quantifications of specific microbial populations, not just total cell counts, in natural samples that can have very low biomasses or features that disrupt quantification methods. For instance, marine sediments themselves can obscure quantifications with FISH and quantitative polymerase chain reaction (99), and extremely small cells might be missed during filtration of water samples (94). However, a method that accurately quantifies the absolute cellular abundance of particular taxonomic groups in natural deep subsurface samples has yet to be developed.

\subsection{Pressure Effects}

All lifeforms depend on the chemistry and physics of self-replicating and self-assembling macromolecules, such as proteins, to catalyze the chemical reactions described above. The goal of research in extreme biophysics is to understand how extreme physical conditions affect the fundamental processes responsible for sustaining life. This includes understanding mechanisms of molecular adaptation to extreme conditions and the driving forces of evolution throughout geologic ages.

Much of life on Earth exists under what are considered extreme conditions of pressure: $88 \%$ of the volume of the oceans is at an average pressure of $38 \mathrm{MPa}$, the deepest trenches can exceed $100 \mathrm{MPa}$, and microbes exist at pressures as much as threefold higher deep in Earth's crust (128). The biomass in high-pressure environments may exceed that on the surface (128). In the oceans, temperature decreases with depth until it reaches an almost constant $3^{\circ} \mathrm{C}$ with pressure as high as 1000 atmospheres (128). Most of the high-pressure ocean is cold and dark, with minimal sources of carbon and minerals and with a low but constant concentration of oxygen. In contrast, temperatures of the water exiting hydrothermal vents in the deep oceans can reach $400^{\circ} \mathrm{C}$, with a temperature gradient so large that the temperature decreases to $3^{\circ} \mathrm{C}$ only $1 \mathrm{~m}$ from the vent. This large temperature gradient on the ocean's floor may be partly responsible for the highly diversified and dynamic deep subsurface microbiome. In the deep subcontinental crust, the total volume in the hydrated fissures in the rock is a large proportion of the biosphere, estimated to be $1016 \mathrm{~m}^{3}$ and 23-31 Pg of carbon $(128,129)$. If only $1 \%$ of that volume is occupied by microorganisms, their biological productivity could be greater than that of Earth's surface (128). It is truly remarkable that life manages to exist in such extreme environments compared to the benign conditions in which humans exist.

\subsubsection{Extreme Molecular Biophysics}

The structures, interactions, and functions of biological macromolecules are highly sensitive to temperature, pressure, $\mathrm{pH}$, salinity, and the concentration of small osmolytes. Take, for example, proton/sodium-coupled electron transfer (PCET) processes, which are central to energy production. The molecular machinery for $\mathrm{H}^{+}$-coupled ATP synthesis is 
essentially the same across most living cells; ATP synthesis succeeds regardless of physical conditions, even though the chemistry of $\mathrm{H}^{+}$-driven processes in biological macromolecules is highly sensitive to pressure, temperature, and salinity. The adaptive mechanisms for PCET under extreme conditions are unknown. Likewise, the physical properties of both the proteins and nucleic acids that drive the central dogma are highly sensitive to temperature, pressure, $\mathrm{pH}$, and salinity, and yet DNA transcription and translation succeed even in extreme environments. The importance of understanding the molecular mechanisms of adaptation of fundamental biochemical processes to extreme conditions cannot be overstated. Somehow, in these extreme environments, adaptations take place so that the essential processes necessary to sustain life can proceed unimpeded.

Whereas structure-function-thermodynamics relationships in proteins from thermophiles have been studied extensively, studies on the adaptation to high pressure are limited (130). Notable exceptions are pressure-adapted RNA polymerases (131), metabolic enzymes (132-138), the bacterial chromosome organizer, histone-like nucleoid structuring proteins (139), G-protein-coupled receptors in deep-sea fish $(140,141)$, and single-stranded DNA binding proteins (142). In addition to identifiable adaptations at the level of the protein's primary sequence, pressure adaptation at the cellular level has been shown to involve changes in gene expression (143), such as upregulation of specific transport proteins of the outer membrane protein (OMP) family $(144,145)$ and the production of osmolytes (146-149), chaperones $(150,151)$, polyamines (152), and modified lipids (149,150,153-155) (Figure 18.6).

Biophysical aspects of adaptation to extreme environments are poorly understood, although the effects of extreme conditions on mesophilic organisms have been studied extensively. Pressure can modulate the conformation of lipid bilayers, nucleic acids, and proteins (156). In the case of nucleic acids, structures can be either stabilized or destabilized by pressure (157), although in general, RNA and DNA molecules exhibiting tertiary structures, such as hairpins, quadruplexes, and ribozymes, are disrupted by pressure $(158,159)$. Lipid bilayers are compressed and thickened in response to pressure and become much less dynamic. The melting temperature for gel to liquid crystalline transitions increases with pressure, and organisms living at high pressures are known to have a higher proportion of unsaturated lipids in their bilayers to maintain an appropriate degree of fluidity.

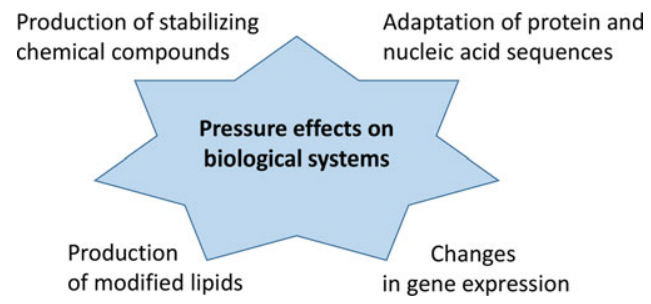

Figure 18.6 Mechanisms of pressure adaptation. 
It has long been known that hydrostatic pressure leads to protein unfolding (160) and oligomer dissociation $(161,162)$. Pressure effects on protein structure arise from differences in molar volume between different conformational states. The molar volume of the unfolded states of proteins $(\mathrm{U})$ is generally smaller than that of their folded states $(\mathrm{F})$ (Figure 18.7), as is the molar volume of monomeric subunits compared to oligomeric species. Pressure shifts the folding/association equilibria toward the state that occupies the lowest molar volume: the unfolded or dissociated states. The values of these volume changes are quite small, typically $<150 \mathrm{~mL} / \mathrm{mol}$ for the unfolding of small globular proteins and $<300 \mathrm{~mL} / \mathrm{mol}$ for the dissociation of oligomers.

Although the differences in volume between conformational or oligomeric states of proteins have been well known for some time $(165,166)$, their structural origins remained obscure and were hotly debated until recently. It has been shown repeatedly that substitution of a large hydrophobic amino acid side chain such as leucine, isoleucine, or even valine by a smaller one such as alanine or glycine invariably leads to a larger overall magnitude of the volume change of unfolding and to greater sensitivity to pressure (167-169). A very strong correlation exists between the volume change of unfolding and the packing density (fractional void volume) of a given protein.

(a)

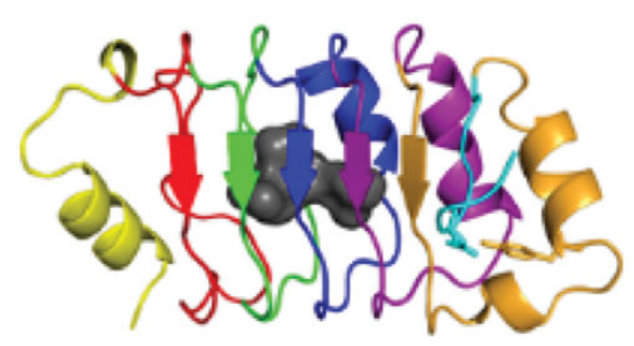

(b)

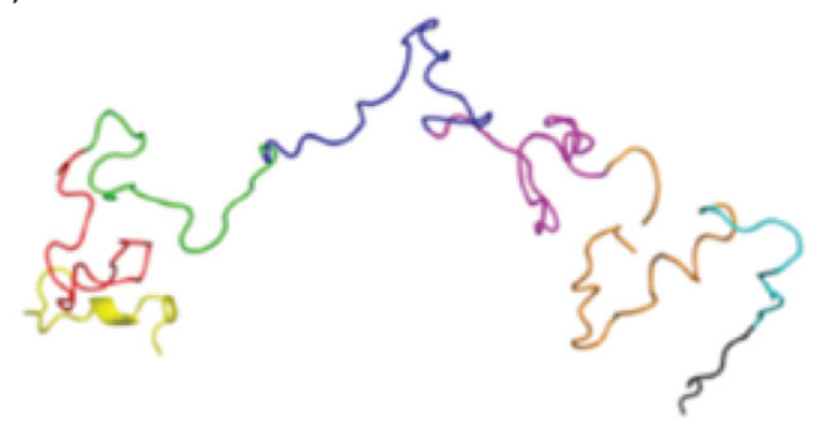

Figure 18.7 Schematic diagrams of a folded (a) and unfolded protein (b), in this case the pp32 leucine-rich repeat protein

(adapted from 163). Cavities in (a) were calculated with a 1.4- $\AA$ sphere using HOLLOW (164). 
The destabilization of any given protein by pressure is larger at low temperatures. Chen and Makhatadze proposed that hydration not only does not cause pressure-induced protein unfolding, but actually makes a strong contribution that opposes pressure-induced unfolding (170). However, as temperature increases, the increase in internal void volume becomes smaller than the effects of hydration, and thus the compensation effect diminishes and the overall difference in molar volume between folded and unfolded states diminishes (171), and can even change sign.

Many aspects of the thermodynamic and structural pressure effects on proteins and adaptations to high-pressure environments remain unknown. It was recently shown that there is no pressure-specific "piezolytes" (i.e. there are no specific volumetric effects associated with low-molecular-weight osmolytes). Rather, their effect is simply to stabilize folded proteins against all manner of perturbations, not specifically high hydrostatic pressure (172). It is not well understood whether there are inherent, specific physical attributes of proteins and nucleic acids that allow them to tolerate high-pressure environments. On a larger scale, the ensemble of different organisms in a given environment may modulate biomolecular adaptation through the physical properties of the biomolecules. Large-scale structural adaptive differences may even be identifiable through comparison of whole genomes.

The populations of folding intermediates and low-lying alternative states implicated in the function, degradation, or aggregation of proteins from piezophiles may be different from those of their mesophilic homologs $(173,174)$, Thus, proteins from piezophiles may have evolved to modulate the population of such species.

Thankfully, through sustained progress in instrumentation for fundamental physicochemical studies of the effects of pressure on biological molecules, the biophysics community is well positioned to address outstanding issues in biomolecular adaptation. Highpressure nuclear magnetic resonance (NMR) measurements, once restricted to a few centers with specialized equipment (175-178), have been adapted for low cost and ease of use with high-field NMR spectrometers $(179,180)$. High-pressure small-angle X-ray and neutron scattering devices are available at several facilities in Japan (181), Europe (182), and in the United States (169). Fluorescence, Fourier-transform infrared spectroscopy, and ultraviolet-visible spectroscopy have long been used in high-pressure biophysical research, and electron paramagnetic resonance and circular dichroism spectroscopy have recently been adapted $(183,184)$. Similarly, high-precision modern microcalorimeters are commercially available, as are electronically controlled, temperature-regulated cells for optical spectroscopic equipment. The range of temperature-pressure studies of biological macromolecules that are possible is broad.

\subsubsection{Extreme Cellular Biophysics}

In the deep-sea bacterium Photobacterium profundum (145), pressure affected the expression of many genes that code for proteins implicated in nutrient transport, such as outer membrane proteins (Omps). In the yeast Saccharomyces cerevisiae (185), pressure affected 
the expression of heat-shock and metabolic proteins. Upregulation of heat-shock and coldshock protein expression in E. coli in response to high pressure has also been reported (186). It has also been shown that pressure shock of around 1000 bar leads to the filamentation of E. coli (187), and $40 \mathrm{MPa}$ has the same effect on piezophilic Desulfovibrio indonesiensis (188), although there are likely multiple mechanisms by which this occurs. Pressure may lead to the dissociation of FtsZ, a tubulin-type GTPase involved in forming the bacterial septum for cell division (189). However, certain strains of E. coli bear a pressure-activated Type IV restriction endonuclease, Mrr, which leads to a pressuredependent SOS response and subsequent filamentation (190,191). The molecular mechanism of the pressure-induced SOS response was shown to be due to pressure-induced dissociation of the inactive Mrr tetramer to an active Mrr dimer that cleaves cryptic sites on the E. coli chromosome (Figure 18.8).

Although genetics, genomics, and transcriptomics can provide an overview of the putative mechanisms of adaptation to life under extreme pressures, these studies provide little biophysical insight. The study of extreme conditions on living cells remains a daunting technological challenge and requires the implementation of high-pressure quantitative microscopy approaches. A few high-pressure microscope chambers have been developed, although they have not been widely used. In the 1970s, Salmon and coworkers developed a phase contrast microscope that could withstand about 800 bar pressure

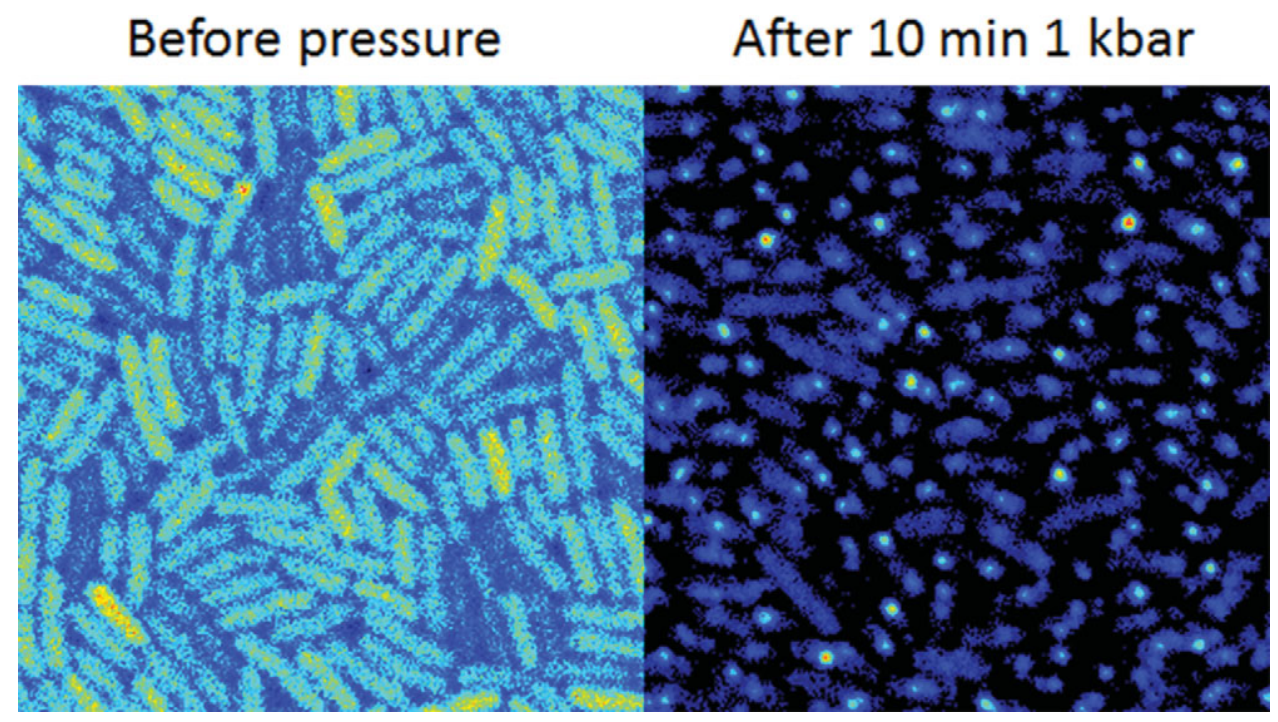

Figure 18.8 Average fluorescence intensity images of GFP-Mrr expressed from an aranbinoseinducible promoter $\left(\mathrm{P}_{\mathrm{BAD}}\right)$ at the natural chromosomal locus in E. coli MG1655. (Left) Cells prior to the application of pressure. Full scale is $0-1.48$ photon counts per $40 \mu$ s. (Right) After 10 minutes at $1 \mathrm{kbar}$ and release of pressure. Full scale is $0.5-6.7$ photon counts per $40 \mu \mathrm{s}$. Both images are $20 \times 20 \mu \mathrm{m}$.

Results are similar to those published in (192). 
$(193,194)$. Müller and Gratton pioneered the use of capillary tubing for high-pressure microscopy (195) that can withstand pressures up to 6000 bar. However, it has never been applied to live cell imaging. Quantitative analysis of pressure effects on bacterial mobility and flagellar rotation speed were accomplished using a recently designed high-pressure microscopy chamber (196). Unfortunately, owing to the thick windows of this cell, it is not suited for the high-magnification objectives required for advanced quantitative microscopy. This limitation is also the case for two other reported high-pressure microscope chamber designs $(197,198)$. Another hurdle will be the genetic manipulation of extremophile organisms in order to insert fluorescent proteins or other tags into the natural loci of genes of interest.

As in the case of high-pressure molecular biophysics, many unknowns exist regarding the molecular strategies used by cells to adapt to high-pressure or to other extreme conditions. There may be common trends (e.g. dependence on osmolytes) among different types of extremophiles. It is possible that the mechanical properties of high-pressure organisms may be different from those of their mesophilic counterparts or of hyperthermophiles, especially in their membranes and signal transduction pathways. Extreme conditions may affect cell state transitions, growth, differentiation, and development in extremophiles, or even the appearance of multicellularity. Changing geochemical conditions on Earth may have affected cellular phenotypes and the evolution of biological macromolecules.

\subsection{Limits to Knowledge and Unknowns}

Some of the most fundamental questions about how life on Earth evolved, especially during the first 4 billion years after Earth was formed, relate to how cells and the molecules that keep them alive adapted to changing extreme conditions. Owing to progress in genomics and in molecular and cellular biophysics, the stage is set for a rigorous and systematic examination of some of the most interesting unanswered questions about the evolution of biological systems.

Future work should focus on determining what sorts of physiological properties can be assigned to uncultured subsurface microbes, and perhaps using those insights to develop new techniques to bring them into culture. Linking the experimental work in extreme biophysics with the new frontiers being opened by coupling genomics, transcriptomics, proteomics, and metabolomics with biogeochemical analyses will yield many exiting discoveries about the deep subsurface biosphere in the next few years.

\section{Acknowledgments}

Funding provided by the Deep Carbon Observatory, especially within the Deep Life community and Census of Deep Life, has enriched much of the research described herein. Funding for this chapter was provided by an Alfred P. Sloan Research Fellowship 
(FG-2015-65399) and NASA Exobiology grant NNX16AL59G to KGL, NSF grants 1745061 and 1660873 to CSS, NSF MCB grant 1514575 to CAR, and NSF MCB grant 1517378 to BG-M.

\section{Questions for the Classroom}

1 What novel techniques have enabled the study of uncultured microbes in the deep subsurface?

2 What are the limitations of some of these novel techniques?

3 What are some general features of metabolism in the deep subsurface biosphere?

4 What are some key ways that high pressure impacts biomolecules?

5 What are some of the novel techniques in use for high-pressure biophysics?

\section{References}

1. Kallmeyer J, Pockalny R, Adhikari RR, Smith DC, D'Hondt S. Global distribution of microbial abundance and biomass in subseafloor sediment. Proc Natl Acad Sci. 2012;109(40):16213-16216.

2. Parkes RJ, Cragg BA, Bale SJ, Getliff JM, Goodman K, Rochelle PA, et al. Deep bacterial biosphere in Pacific Ocean sediments. Nature. 1994;371:410-413.

3. Head IM, Jones DM, Röling WFM. Marine microoganisms make a meal of oil. Nat Rev Microbiol. 2006;4:173-182.

4. Wrighton KC, Thomas BC, Sharon I, Miller CS, Castelle CJ, VerBerkmoes NC, et al. Fermentation, hydrogen, and sulfur metabolism in multiple uncultivated bacterial phyla. Science. 2012;337:1661-1665.

5. Kietäväinen R, Purkamo L. The origin, source, and cycling of methane in deep crystalline rock. Front Microbiol. 2015;6:725.

6. Jørgensen SL, Zhao R. Microbial inventory of deeply buried oceanic crust from a young ridge flank. Front Microbiol. 2016;7:820.

7. Santelli CM, Orcutt BN, Banning E, Bach W, Moyer CL, Sogin ML, et al. Abundance and diversity of microbial life in ocean crust. Nature. 2008;453:5-9.

8. Meyer JL, Jaekel U, Tully BJ, Glazer BT, Wheat CG, Lin H, et al. A distinct and active bacterial community in cold oxygenated fluids circulating beneath the western flank of the Mid-Atlantic ridge. Sci Rep. 2016;6:22541.

9. Mackelprang R, Waldrop MP, Deangelis KM, David MM, Chavarria KL, Blazewicz SJ, et al. Metagenomic analysis of a permafrost microbial community reveals a rapid response to thaw. Nature. 2011;480(7377):368-371.

10. Borgonie G, Linage-Alverez B, Ojo A, Shivambu S, Kuloyo O, Cason ED, Van Heerden E. Deep subsurface mine stalactites trap endemic fissure fluid Archaea, Bacteria, and Nematoda possibly originating from ancient seas. Front Microbiol. 2015;6:833.

11. Parnell J, McMahon S. Physical and chemical controls on habitats for life in the deep subsurface beneath continents and ice. Philos Trans $R$ Soc A Math Phys Eng Sci. 2016;374(2059):20140293. 
12. Huber JA, Mark Welch DB, Morrison HG, Huse SM, Neal PR, Butterfield DA, et al. Microbial population structures in the deep marine biosphere. Science. 2007;318:97-100.

13. Hedlund BP, Murugapiran SK, Alba TW, Levy A, Dodsworth JA, Goertz GB, et al. Uncultivated thermophiles: current status and spotlight on "Aigarchaeota". Curr Opin Microbiol. 2015;25:136-145.

14. Hoehler TM, Jørgensen BB. Microbial life under extreme energy limitation. Nat Rev Microbiol. 2013;11(2):83-94.

15. Daly RA, Borton MA, Wilkins MJ, Hoyt DW, Kountz DJ, Wolfe RA, et al. Microbial metabolisms in a 2.5 -km-deep ecosystem created by hydraulic fracturing in shales. Nat Microbiol. 2016;1:16145.

16. Wilhelms A, Larter SR, Head IM, Farrimond P, Di-Primio R, Zwach C. Biodegradation of oil in uplifted basins prevented by deep-burial sterilization. Nature. 2001;411:1034-1037.

17. Braun S, Mhatre SS, Jaussi M, Røy H, Kjeldsen KU, Seidenkrantz M, et al. Microbial turnover times in the deep seabed studied by amino acid racemization modelling. Sci Rep. 2017;7:5680.

18. Trembath-Reichert E, Morono Y, Ijiri A, Hoshino T, Dawson KS, Inagaki F, et al. Methyl-compound use and slow growth characterize microbial life in 2-km-deep subseafloor coal and shale beds. Proc Natl Acad Sci. 2017;114(44):E9206-E9215.

19. Larowe DE, Amend JP. Power limits for microbial life. Front Microbiol. 2015;6:718.

20. Takai K, Inagaki F, Nakagawa S, Hirayama H, Nunoura T, Sako Y, et al. Isolation and phylogenetic diversity of members of previously uncultivated Epsilon-Proteobacteria in deep-sea hydrothermal fields. FEMS Microbiol Lett. 2003;218:167-174.

21. Edgcomb VP, Beaudoin D, Gast R, Biddle JF, Teske A. Marine subsurface eukaryotes: the fungal majority. Environ Microbiol. 2011;13(1):172-183.

22. Labonté JM, Field EK, Lau M, Chivian D, Heerden E Van, Wommack KE, et al. Single cell genomics indicates horizontal gene transfer and viral infections in a deep subsurface Firmicutes population. Front Microbiol. 2015;6:349.

23. Anderson RE, Beltrán MT, Hallam SJ, Baross JA. Microbial community structure across fluid gradients in the Juan de Fuca Ridge hydrothermal system. FEMS Microbiol Ecol. 2013;83(2):324-339.

24. Sohlberg E, Bomberg M, Miettinen H, Nyyssönen M, Salavirta H, Vikman M, et al. Revealing the unexplored fungal communities in deep groundwater of crystalline bedrock fracture zones in Olkiluoto, Finland. Front Microbiol. 2015;6:573.

25. Engelhardt T, Kallmeyer J, Cypionka H, Engelen B. High virus-to-cell ratios indicate ongoing production of viruses in deep subsurface sediments. ISME J. 2014;8 (7):1503-1509.

26. Lloyd KG, Steen AD, Ladau J, Yin J, Crosby L. Phylogenetically novel uncultured microbial cells dominate Earth microbiomes. mSystems. 2018;3:10.1128/mSystems.00055-18.

27. Imachi H, Aoi K, Tasumi E, Saito Y, Yamanaka Y, Saito Y, et al. Cultivation of methanogenic community from subseafloor sediments using a continuous-flow bioreactor. ISME J. 2011;5(12):1913-1925.

28. Parkes RJ, Sellek G, Webster G, Martin D, Anders E, Weightman AJ, et al. Culturable prokaryotic diversity of deep, gas hydrate sediments: first use of a continuous high-pressure, anaerobic, enrichment and isolation system for subseafloor sediments (DeepIsoBUG). Environ Microbiol. 2009;11:3140-3153. 
29. Boone DR, Liu Y, Zhao Z, Balkwill DL, Drake GR, Stevens T, et al. Bacillus infernus sp. nov., an Fe(III)- and Mn(IV)-reducing anaerobe from the deep terrestrial subsurface. Int J Syst Bacteriol. 1995;45(3):441-448.

30. Russell JA, León-zayas R, Wrighton K, Biddle JF. Deep subsurface life from North Pond: enrichment, isolation, characterization and genomes of heterotrophic bacteria. Front Microbiol. 2016;65:678.

31. Bonis BM, Gralnick JA. Marinobacter subterrani, a genetically tractable neutrophilic Fe(II)-oxidizing strain isolated from the Soudan Iron Mine. Front Microbiol. 2015;6:719.

32. Dodsworth JA, Ong JC, Williams AJ, Dohnalkova AC, Hedlund BP. Thermocrinis jamiesonii sp. nov., a thiosulfate-oxidizing, autotropic thermophile isolated from a geothermal spring. Int J Syst Evol Microbiol. 2015;65:4769-4775.

33. Zinke LA, Reese BK, Mcmanus J, Wheat CG, Orcutt BN, Amend JP. Sediment microbial communities influenced by cool hydrothermal fluid migration. Front Microbiol. 2018;9:1249.

34. Staley JT, Konopka A. Measurement of in situ activities of nonphotosynthetic microorganisms in aquatic and terrestrial habitats. Anпи Rev Microbiol. 1985;39:321-346.

35. Rappé MS, Giovannoni SJ. The uncultured microbial majority. Annu Rev Microbiol. 2003;57:369-394.

36. Hugenholtz P, Goebel BM, Pace NR. Impact of culture-independent studies on the emerging phylogenetic view of bacterial diversity. J Bacteriol. 1998;180(18): 4765-4774.

37. Woese CR, Fox GE. Phylogenetic structure of the prokaryotic domain: the primary kingdoms. Proc Natl Acad Sci. 1977;74(11):5088-5090.

38. Woese CR. Bacterial evolution. Microbiol Rev. 1987;51(2):221-271.

39. Hugenholtz P, Pitulle C, Hershberger KL, Pace NR. Novel division level bacterial diversity in a Yellowstone hot spring. J Bacteriol. 1998;180(2):366-376.

40. Lomstein BA, Langerhuus AT, Hondt SD, Jørgensen BB, Spivack AJ. Endospore abundance, microbial growth and necromass turnover in deep sub-seafloor sediment. Nature. 2012;484:101-104.

41. Lennon JT, Jones SE. Microbial seed banks: the ecological and evolutionary implications of dormancy. Nat Rev Microbiol. 2011;9(2):119-130.

42. Morita RY. Bioavailability of energy and its relationship to growth and starvation survival in nature. Can J Microbiol. 1988;34(4):436-441.

43. Lau MCY, Kieft TL, Kuloyo O, Linage-alvarez B, Heerden E Van, Lindsay MR, et al. An oligotrophic deep-subsurface community dependent on syntrophy is dominated by sulfur-driven autotrophic denitrifiers. Proc Natl Acad Sci. 2016;113(49):E7927-E7936.

44. Lloyd KG, Schreiber L, Petersen DG, Kjeldsen KU, Lever MA, Steen AD, et al. Predominant archaea in marine sediments detrital proteins. Nature. 2013;496:215-218.

45. Orsi WD, Edgcomb VP, Christman GD, Biddle JF. Gene expression in the deep biosphere. Nature. 2013;499:205-208.

46. Sheik CS, Reese BK, Twing KI, Sylvan JB, Grim SL, Schrenk MO, et al. Identification and removal of contaminant sequences from ribosomal gene databases: lessons from the Census of Deep Life. Front Microbiol. 2018;9:840.

47. Salter SJ, Cox MJ, Turek EM, Calus ST, Cookson WO, Moffatt MF et al. Reagent and laboratory contamination can critically impact sequence-based microbiome analyses. BMC Biol. 2014;12:87. 
48. Kogawa M, Hosokawa M, Nishikawa Y, Mori K, Takeyama H. Obtaining highquality draft genomes from uncultured microbes by cleaning and co-assembly of single-cell amplified genomes. Sci Rep. 2018;8(1):2059.

49. Olm MR, Butterfield CN, Copeland A, Boles TC, Thomas BC, Banfield JF. The source and evolutionary history of a microbial contaminant identified through soil metagenomic analysis. MBio. 2017;8(1):e01969.

50. Heintz-Buschart A, Yusuf D, Kaysen A, Etheridge A, Fritz JV, May P, et al. Isolation of nucleic acids from low biomass samples: detection and removal of sRNA contaminants. bioRxiv. 2017;232975.

51. Puente-sánchez AF, Arce-rodríguez A, Oggerin M, Moreno-paz M, Blanco Y, Rodríguez N, et al. Viable cyanobacteria in the deep continental subsurface. Proc Natl Acad Sci. 2018;115(42):10702-10707.

52. Chivian D, Brodie EL, Alm EJ, Culley DE, Dehal PS, DeSantis TZ, et al. Environmental genomics reveals a single-species ecosystem deep within Earth. Science. 2008;322(5899):275-278.

53. Hug LA, Baker BJ, Anantharaman K, Brown CT, Probst AJ, Castelle CJ, et al. A new view of the tree of life. Nat Microbiol. 2016;1:16048.

54. Spang A, Saw JH, Jørgensen SL, Zaremba-niedzwiedzka K, Martijn J, Lind AE, et al. Complex archaea that bridge the gap between prokaryotes and eukaryotes. Nature. 2015;521(7551):173-179.

55. Dick G. Genomic Approaches in Earth and Environmental Sciences. John Wiley \& Sons, 2018.

56. Tyson GW, Chapman J, Hugenholtz P, Allen EE, Ram RJ, Richardson PM, et al. Community structure and metabolism through reconstruction of microbial genomes from the environment. Nature. 2004;428:37-43.

57. Jungbluth SP, Glavina del Rio T, Tringe SG, Stepanauskas R, Rappé MS. Genomic comparisons of a bacterial lineage that inhabits both marine and terrestrial deep subsurface systems. PeerJ. 2017;5:e3134.

58. Schuchmann K, Müller V. Energetics and application of heterotrophy in acteogenic bacteria. Appl Environ Microbiol. 2016;82(14):4056-4069.

59. Wrighton KC, Castelle CJ, Varaljay VA, Satagopan S, Brown CT, Wilkins MJ, et al. RubisCO of a nucleoside pathway known from Archaea is found in diverse uncultivated phyla in bacteria. ISME J. 2016;10(11):2702-2714.

60. Baker BJ, Lazar CS, Teske AP, Dick GJ. Genomic resolution of linkages in carbon, nitrogen, and sulfur cycling among widespread estuary sediment bacteria. Microbiome. 2015;3(1):14.

61. Crespo-Medina M, Twing KI, Sanchez-Murillo R, Brazelton WJ, McCollom TM, Schrenk MO. Methane dynamics in a tropical serpentinizing environment: the Santa Elena ophiolite, Costa Rica. Front Microbiol. 2017;8:916.

62. Brazelton WJ, Nelson B, Schrenk MO. Metagenomic evidence for $\mathrm{H}_{2}$ oxidation and $\mathrm{H}_{2}$ production by serpentinite-hosted subsurface microbial communities. Front Microbiol. 2012;2:268.

63. Hamilton TL, Jones DS, Schaperdoth I, Macalady JL. Metagenomic insights into $\mathrm{S}(0)$ precipitation in a terrestrial subsurface lithoautotrophic ecosystem. Front Microbiol. 2015;5:756.

64. Anantharaman K, Brown CT, Hug LA, Sharon I, Castelle CJ, Probst AJ, et al. Thousands of microbial genomes shed light on interconnected biogeochemical processes in an aquifer system. Nat Commun. 2016;7:13219. 
65. Twing KI, Brazelton WJ, Kubo MDY, Hyer AJ, Cardace D, Hoehler TM, et al. Serpentinization-influenced groundwater harbors extremely low diversity microbial communities adapted to high pH. Front Microbiol. 2017;8:308.

66. Probst AJ, Ladd B, Jarett JK, Geller-Mcgrath DE, Sieber CMK, Emerson JB, et al. Differential depth distribution of microbial function and putative symbionts through sediment-hosted aquifers in the deep terrestrial subsurface. Nat Microbiol. 2018;3(3):328-336.

67. Evans PN, Parks DH, Chadwick GL, Robbins SJ, Orphan VJ, Golding SD, et al. Methane metabolism in the archaeal phylum Bathyarchaeota revealed by genomecentric metagenomics. Science. 2015;350(6259):434-438.

68. Dodsworth JA, Blainey PC, Murugapiran SK, Swingley WD, Ross CA, Tringe SG, et al. Single-cell and metagenomic analyses indicate a fermentative and saccharolytic lifestyle for members of the OP9 lineage. Nat Commun. 2013;4:1854.

69. Delmont TO, Eren AM. Linking pangenomes and metagenomes: the Prochlorococcus metapangenome. PeerJ. 2018;6:e4320.

70. Lloyd KG, Schreiber L, Petersen DG, Kjeldsen KU, Lever MA, Steen AD, et al. Predominant archaea in marine sediments degrade detrital proteins. Nature. 2013;496 (7444):215-218.

71. Fullerton H, Moyer CL. Comparative single-cell genomics of Chloroflexi from the Okinawa trough deep-subsurface biosphere. Appl Environ Microbiol. 2016;82 (10):3000-3008.

72. Swan BK, Martinez-García M, Preston CM, Sczyrba A, Woyke T, Lamy D, et al. Potential for chemolithoautotrophy among ubiquitous bacteria lineages in the dark ocean. Science. 2011;333(6047):1296-1300.

73. Moran MA, Satinsky B, Gifford SM, Luo H, Rivers A, Chan LK et al. Sizing up metatranscriptomics. ISME J. 2013;7(2):237-243.

74. Jewell TNM, Karaoz U, Brodie EL, Williams KH, Beller HR. Metatranscriptomic evidence of pervasive and diverse chemolithoautotrophy relevant to $\mathrm{C}, \mathrm{S}, \mathrm{N}$ and $\mathrm{Fe}$ cycling in a shallow alluvial aquifer. ISME J. 2016;10(9):2106-2117.

75. Baker BJ, Sheik CS, Taylor CA, Jain S, Bhasi A, Cavalcoli JD, et al. Community transcriptomic assembly reveals microbes that contribute to deep-sea carbon and nitrogen cycling. ISME J. 2013;7(10):1962-1973.

76. Blazewicz SJ, Barnard RL, Daly RA, Firestone MK. Evaluating rRNA as an indicator of microbial activity in environmental communities: limitations and uses. ISME J. 2013;7(11):2061-2068.

77. Wrighton KC, Castelle CJ, Wilkins MJ, Hug LA, Sharon I, Thomas BC, et al. Metabolic interdependencies between phylogenetically novel fermenters and respiratory organisms in an unconfined aquifer. ISME J. 2014;8(7):1452-1463.

78. Bird JT, Tague E, Zinke L, Schmidt JM, Steen AD, Reese B, et al. Uncultured microbial phyla suggest mechanisms for multi-thousand-year subsistence in Baltic Sea sediments. mBio. 2019;10(2):e02376-18.

79. Giovannelli D, Sievert SM, Hügler M, Markert S, Becher D, Schweder T, et al. Insight into the evolution of microbial metabolism from the deep-branching bacterium, Thermovibrio ammonificans. Elife. 2017;6:e18990.

80. Moore EK, Jelen BI, Giovannelli D, Raanan H, Falkowski PG. Metal availability and the expanding network of microbial metabolisms in the Archaean eon. Nat Geosci. 2017;10:629-636.

81. Nealson KH. Sediment bacteria: who's there, what are they doing, and what's new? Annu Rev Earth Planet Sci. 1997;25:403-434. 
82. Froelich PN, Klinkhammer GP, Bender ML, Luedtke NA, Heath GR, Cullen D, et al. Early oxidation of organic matter in pelagic sediments of the eastern equatorial Atlantic: suhoxic diagenesis. Geochim Cosmochim Acta. 1979;43(7):1075-1090.

83. D'Hondt S, Rutherford S, Spivack AJ. Metabolic activity of subsurface life in deepsea sediments. Science. 2002;295(5562):2067-2070.

84. Durbin AM, Teske A. Archaea in organic-lean and organic-rich marine subsurface sediments: an environmental gradient reflected in distinct phylogenetic lineages. Front Microbiol. 2012;3:168.

85. D'Hondt S, Spivack AJ, Pockalny R, Ferdelman TG, Fischer JP, Kallmeyer J, et al. Subseafloor sedimentary life in the South Pacific Gyre. Proc Natl Acad Sci. 2009;106 (28):11651-11656.

86. Røy H, Kallmeyer J, Adhikari RR, Pockalny R, Jørgensen BB, D’Hondt S. Aerobic microbial respiration in 86-million-year-old deep-sea red clay. Science. 2012;336 (6083):922-925.

87. Magnabosco C, Ryan K, Lau MCY, Kuloyo O, Lollar BS, Kieft TL, et al. A metagenomic window into carbon metabolism at $3 \mathrm{~km}$ depth in Precambrian continental crust. ISME J. 2015;10(3):730-741.

88. Cragg B, Harvey S, Fry J, Herbert R, Parkes R. Bacterial biomass and activity in the deep sediment layers of the Japan Sea, Hole 798B. Proc Ocean Drill Progr. 1992;128:761-775.

89. Orcutt BN, LaRowe DE, Biddle JF, Colwell FS, Glazer BT, Reese BK, et al. Microbial activity in the marine deep biosphere: progress and prospects. Front Microbiol. 2013;4:1-15.

90. Purkamo L, Bomberg M, Kietäväinen R, Salavirta H, Nyyssönen M. Microbial cooccurrence patterns in deep Precambrian bedrock fracture fluids. Biogeosciences. 2016;13:3091-3108.

91. Durbin AM, Teske A. Microbial diversity and stratification of South Pacific abyssal marine sediments. Environ Microbiol. 2011;13(12):3219-3234.

92. Beulig F, Røy H, Glombitza C, Jørgensen BB. Control on rate and pathway of anaerobic organic carbon degradation in the seabed. Proc Natl Acad Sci. 2018;115 (2):367-372.

93. Braun S, Morono Y, Littmann S, Kuypers M, Aslan H, Dong M, et al. Size and carbon content of sub-seafloor microbial cells at Landsort Deep, Baltic Sea. Front Microbiol. 2016;7:1375.

94. Baker BJ, Comolli LR, Dick GJ, Hauser LJ, Hyatt D, Dill BD, et al. Enigmatic, ultrasmall, uncultivated Archaea. Proc Natl Acad Sci. 2010;107(19):8806-8811.

95. Takano Y, Chikaraishi Y, Ogawa NO, Nomaki H, Morono Y, Inagaki F, et al. Sedimentary membrane lipids recycled by deep-sea benthic archaea. Nat Geosci. 2010;3(12):858-861.

96. Amann R, Fuchs BM, Behrens S. The identification of microorganisms by fluorescence in situ hybridisation. Curr Opin Biotechnol. 2001;12(3):231-236.

97. Pernthaler A, Amann R. Simultaneous fluorescence in situ hybridization of mRNA and rRNA in environmental bacteria. Appl Environ Microbiol. 2004;70(9):5426-5433.

98. Morono Y, Terada T, Nishizawa M, Ito M, Hillion F, Takahata N, et al. Carbon and nitrogen assimilation in deep subseafloor microbial cells. Proc Natl Acad Sci. 2011;108(45):18295-18300.

99. Lloyd KG, May MK, Kevorkian RT, Steen AD. Meta-analysis of quantification methods shows that archaea and bacteria have similar abundances in the subseafloor. Appl Environ Microbiol. 2013;79(24):7790-7799. 
100. Buongiorno J, Turner S, Webster G, Asai M, Shumaker AK, Roy T, et al. Interlaboratory quantification of Bacteria and Archaea in deeply buried sediments of the Baltic Sea (IODP Expedition 347). FEMS Microbiol Ecol. 2017;93(3):fix007.

101. Inagaki F, Kubo Y, Bowles MW, Heuer VB, Ijiri A, Imachi H, et al. Exploring deep microbial life in coal-bearing sediment down to $\sim 2.5 \mathrm{~km}$ below the ocean floor. Science. 2015;349:420-424.

102. Trembath-Reichert E, Morono Y, Ijiri A, Hoshino T, Dawson KS, Inagaki F, et al. Methyl-compound use and slow growth characterize microbial life in 2-km-deep subseafloor coal and shale beds. Proc Natl Acad Sci. 2017;114(44):E9206-E9215.

103. Ijiri A, Inagaki F, Kubo Y, Adhikari RR, Hattori S, Hoshino T, et al. Deep-biosphere methane production stimulated by geofluids in the nankai accretionary complex. Sci Adv. 2018;4(6):eaao4631.

104. Hatzenpichler R, Scheller S, Tavormina PL, Babin BM, Tirrell DA, Orphan VJ. In situ visualization of newly synthesized proteins in environmental microbes using amino acid tagging and click chemistry. Environ Microbiol. 2014;16:2568-2590.

105. Hatzenpichler R, Connon SA, Goudeau D, Malmstrom RR, Woyke T, Orphan VJ. Visualizing in situ translational activity for identifying and sorting slow-growing archaeal-bacterial consortia. Proc Natl Acad Sci. 2016;113(28):E4069-E4078.

106. Bradley JA, Amend JP, Larowe DE. Necromass as a limited source of energy for microorganisms in marine sediments. J Geophys Res Biogeosci. 2018;123(2): $577-590$.

107. Lin L, Hall J, Lippmann-pipke J, Ward JA, Lollar BS, Deflaun M, et al. Radiolytic $\mathrm{H}_{2}$ in continental crust: nuclear power for deep subsurface microbial communities. Geochem Geophys Geosyst. 2005;6(7):Q07003.

108. Blair CC, D'Hondt S, Spivack AJ, Kingsley RH. Radiolytic hydrogen and microbial respiration in subsurface sediments. Astrobiology. 2007;7(6):951-970.

109. Ménez B, Pasini V, Brunelli D. Life in the hydrated suboceanic mantle. Nat Geosci. 2012;5(2):133-137.

110. Suzuki S, Wu A, Cheung A, Tenney A, Wanger G, Kuenen JG, et al. Microbial diversity in The Cedars, an ultrabasic, ultrareducing, and low salinity serpentinizing ecosystem. Proc Natl Acad Sci. 2013;110(38):15336-15341.

111. Brazelton WJ, Schrenk MO, Kelley DS, Baross JA. Methane- and sulfurmetabolizing microbial communities dominate the Lost City hydrothermal field ecosystem. Appl Environ Microbiol. 2006;72(9):6257-6270.

112. Lang SQ, Früh-Green GL, Bernasconi SM, Brazelton WJ, Schrenk MO, McGonigle JM. Deeply-sourced formate fuels sulfate reducers but not methanogens at Lost City hydrothermal field. Sci Rep. 2018;8(1):755.

113. Hug LA, Thomas BC, Brown CT, Frischkorn KR, Williams KH, Tringe SG, et al. Aquifer environment selects for microbial species cohorts in sediment and groundwater. ISME J. 2015;9(8):1846-1856.

114. Rinke C, Schwientek P, Sczyrba A, Ivanova NN, Anderson IJ, Cheng J-F, et al. Insights into the phylogeny and coding potential of microbial dark matter. Nature. 2013;499(7459):431-437.

115. Thorup C, Schramm A, Findlay AJ, Finster KW, Schreiber L. Disguised as a sulfate reducer: growth of the deltaproteobacterium Desulfurivibrio alkaliphilus by sulfide oxidation with nitrate. MBio. 2017;8(4):e00671-17.

116. Laso-pérez R, Wegener G, Knittel K, Widdel F, Harding KJ, Krukenberg V, et al. Thermophilic archaea activate butane via alkyl-coenzyme $\mathrm{M}$ formation. Nature. 2016;539(7629):396-401. 
117. Michalska K, Steen AD, Chhor G, Endres M, Webber AT, Bird J, et al. New aminopeptidase from "microbial dark matter" archaeon. FASEB J. 2015;29:4071-4079.

118. Kantor RS, Wrighton KC, Handley KM, Sharon I, Hug LA, Castelle CJ, et al. Small genomes and sparse metabolisms of sediment-associated bacteria from four candidate phyla. MBio. 2013;4(5):e00708-e00713.

119. Smith SA, Tabita FR. Positive and negative selection of mutant forms of prokaryotic (cyanobacterial) ribulose-1,5,bisphosphate carboxylase/oxygenase. $J$ Mol Biol. 2003;331:557-569.

120. Lever MA, Rogers KL, Lloyd KG, Overmann J, Schink B, Thauer RK, et al. Life under extreme energy limitation: a synthesis of laboratory- and field-based investigations. FEMS Microbiol Rev. 2015;39(5):688-728.

121. Jørgensen BB, Marshall IPG. Slow microbial life in the seabed. Annu Rev Mar Sci. 2016;8:311-332.

122. Robador A, Larowe DE, Finkel SE, Amend JP, Nealson KH, Booth V. Changes in microbial energy metabolism measured by nanocalorimetry during growth phase transitions. Front Microbiol. 2018;9:109.

123. Timmers PH, Gieteling J, Widjaja-Greefkes HCA, Plugge CM, Stams AJM, Lens PNL, et al. Growth of anaerobic methane-oxidizing archaea and sulfate-reducing bacteria in a high-pressure membrane capsule bioreactor. Appl Environ Microbiol. 2015;81(4):1286-1296.

124. Finkel SE. Long-term survival during stationary phase: evolution and the GASP phenotype. Nat Rev Microbiol. 2006;4(2):113-120.

125. Kevorkian R, Bird JT, Shumaker A, Lloyd KG. Estimating population turnover rates by relative quantification methods reveals microbial dynamics in marine sediment. Appl Environ Microbiol. 2018;84(1):e01443-17.

126. Steen AD, Jorgensen BB, Lomstein BA. Abiotic racemization kinetics of amino acids in marine sediments. PLoS One. 2013;8(8):e71648.

127. Onstott TC, Magnabosco C, Aubrey AD, Burton AS, Dworkin JP, Elsila JE, et al. Does aspartic acid racemization constrain the depth limit of the subsurface biosphere? Geobiology. 2014;12:1-19.

128. Daniel I, Oger P, Winter R. Origins of life and biochemistry under high-pressure conditions. Chem Soc Rev. 2006;35(10):858-875.

129. Magnabosco C, Lin L-H, Dong H, Bomberg M, Ghiorse W, Stan-Lotter H, et al. The biomass and biodiversity of the continental subsurface. Nat Geosci. 2018;11:707-717.

130. Cavicchioli R, Thomas T, Curmi PMG. Cold stress response in Archaea. Extremophiles. 2000;4(6):321-331.

131. Kawano H, Nakasone K, Matsumoto M, Yoshida Y, Usami R, Kato C, et al. Differential pressure resistance in the activity of RNA polymerase isolated from Shewanella violacea and Escherichia coli. Extremophiles. 2004;8(5):367-375.

132. Kasahara R, Sato T, Tamegai H, Kato C. Piezo-adapted 3-isopropylmalate dehydrogenase of the obligate piezophile Shewanella benthica DB21MT-2 isolated from the 11,000-m depth of the Mariana Trench. Biosci Biotechnol Biochem. 2009;73(11):2541-2543.

133. Hay S, Evans RM, Levy C, Loveridge EJ, Wang X, Leys D, et al. Are the catalytic properties of enzymes from piezophilic organisms pressure adapted? ChemBioChem. 2009;10(14):2348-2353.

134. Nishiguchi Y, Abe F, Okada M. Different pressure resistance of lactate dehydrogenases from hagfish is dependent on habitat depth and caused by tetrameric structure dissociation. Mar Biotechnol. 2011;13(2):137-141. 
135. Hamajima Y, Nagae T, Watanabe N, Ohmae E, Kato-Yamada Y, Kato C. Pressure adaptation of 3-isopropylmalate dehydrogenase from an extremely piezophilic bacterium is attributed to a single amino acid substitution. Extremophiles. 2016;20(2):177-186.

136. Rosenbaum E, Gabel F, Durá MA, Finet S, Cléry-Barraud C, Masson P, et al. Effects of hydrostatic pressure on the quaternary structure and enzymatic activity of a large peptidase complex from Pyrococcus horikoshii. Arch Biochem Biophys. 2012; 517(2):104-110.

137. Murakami C, Ohmae E, Tate S, Gekko K, Nakasone K, Kato C. Comparative study on dihydrofolate reductases from Shewanella species living in deep-sea and ambient atmospheric-pressure environments. Extremophiles. 2011;15(2):165-175.

138. De Vos D, Xu Y, Hulpiau P, Vergauwen B, Van Beeumen JJ. Structural investigation of cold activity and regulation of aspartate carbamoyltransferase from the extreme psychrophilic bacterium Moritella profunda. J Mol Biol. 2007;365(2): 379-395.

139. Jian $\mathrm{H}, \mathrm{Xu} \mathrm{G}, \mathrm{Gai} \mathrm{Y}, \mathrm{Xu} \mathrm{J}, \mathrm{Xiao} \mathrm{X}$. The histone-like nucleoid structuring protein (H-NS) is a negative regulator of the lateral flagellar system in the deep-sea bacterium Shewanella piezotolerans WP3. Appl Environ Microbiol. 2016;82(8):2388-2398.

140. Siebenaller JF. Pressure effects on the GTPase activity of brain membrane G proteins of deep-living marine fishes. Comp Biochem Physiol B Biochem Mol Biol. 2003;135 (4):697-705.

141. Siebenaller JF, Garrett DJ. The effects of the deep-sea environment on transmembrane signaling. Comp Biochem Physiol B Biochem Mol Biol. 2002;131(4):675-694.

142. Chilukuri LN, Bartlett DH, Fortes PAG. Comparison of high pressure-induced dissociation of single-stranded DNA-binding protein (SSB) from high pressuresensitive and high pressure-adapted marine Shewanella species. Extremophiles. 2002;6(5):377-383.

143. Boonyaratanakornkit BB, Miao LY, Clark DS. Transcriptional responses of the deepsea hyperthermophile Methanocaldococcus jannaschii under shifting extremes of temperature and pressure. Extremophiles. 2007;11(3):495-503.

144. Simonato F, Campanaro S, Lauro FM, Vezzi A, D’Angelo M, Vitulo N, et al. Piezophilic adaptation: a genomic point of view. J Biotechnol. 2006;126(1):11-25.

145. Campanaro S, De Pascale F, Telatin A, Schiavon R, Bartlett DH, Valle G. The transcriptional landscape of the deep-sea bacterium Photobacterium profundum in both a toxR mutant and its parental strain. BMC Genomics. 2012;13:567.

146. Samerotte AL, Drazen JC, Brand GL, Seibel BA, Yancey PH. Correlation of trimethylamine oxide and habitat depth within and among species of teleost fish: an analysis of causation. Physiol Biochem Zool. 2007;80(2):197-208.

147. Nagae T, Kawamura T, Chavas LMG, Niwa K, Hasegawa M, Kato C, et al. Highpressure-induced water penetration into 3-isopropylmalate dehydrogenase. Acta Crystallogr Sect D Biol Crystallogr. 2012;68(3):300-309.

148. Kaye JZ, Baross J. Synchronous effects of temperature, hydrostatic pressure, and salinity on growth, phospholipid profiles, and protein patterns of four Halomonas species isolated from deep-sea hydrothermal-vent and sea surface environments. Appl Environ Microbiol. 2004;70(10):6220-6229.

149. Bartlett DH. Pressure effects on in vivo microbial processes. Biochim Biophys Acta Protein Struct Mol Enzymol. 2002;1595(1):367-381.

150. Campanaro S, Treu L, Valle G. Protein evolution in deep sea bacteria: an analysis of amino acids substitution rates. BMC Evol Biol. 2008;8(1):313. 
151. Cario A, Jebbar M, Thiel A, Kervarec N, Oger PM. Molecular chaperone accumulation as a function of stress evidences adaptation to high hydrostatic pressure in the piezophilic archaeon Thermococcus barophilus. Sci Rep. 2016;6(1):29483.

152. Nakashima M, Yamagami R, Tomikawa C, Ochi Y, Moriya T, Asahara H, et al. Long and branched polyamines are required for maintenance of the ribosome, tRNAHis and tRNATyr in Thermus thermophilus cells at high temperatures. Genes Cells. 2017;22(7):628-645.

153. Michoud G, Jebbar M. High hydrostatic pressure adaptive strategies in an obligate piezophile Pyrococcus yayanosii. Sci Rep. 2016;6:27289.

154. Eloe EA, Malfatti F, Gutierrez J, Hardy K, Schmidt WE, Pogliano K, et al. Isolation and characterization of a psychropiezophilic alphaproteobacterium. Appl Environ Microbiol. 2011;77(22):8145-8153.

155. Jebbar M, Franzetti B, Girard E, Oger P. Microbial diversity and adaptation to high hydrostatic pressure in deep-sea hydrothermal vents prokaryotes. Extremophiles. 2015;19(4):721-740.

156. Winter R, Dzwolak W. Exploring the temperature-pressure configurational landscape of biomolecules: from lipid membranes to proteins. Philos Trans A Math Phys Eng Sci. 2005;363(1827):537-562; discussion 562-563.

157. Macgregor RB. Effect of hydrostatic, pressure on nucleic acids. Biopolymers. 1998;48(4):253-263.

158. Fan HY, Shek YL, Amiri A, Dubins DN, Heerklotz H, Macgregor Jr. RB, et al. Volumetric characterization of sodium-induced G-quadruplex formation. $J$ Am Chem Soc. 2011;133(12):4518-4526.

159. Amiri AR, Macgregor Jr. RB. The effect of hydrostatic pressure on the thermal stability of DNA hairpins. Biophys Chem. 2011;156(1):88-95.

160. Bridgman. The coagulation of albumin by pressure. J Biol Chem. 1914;19:511-512.

161. Weber G. Thermodynamics of the association and the pressure dissociation of oligomeric proteins. J Phys Chem. 1993;97(27):7108-7115.

162. Schmid G, Ludemann H-D, Jaenicke R. Dissociationand aggregation of lactic dehydrogenase by high hydrostatic pressure. Eur J Biochem. 1979;97:407-413.

163. Fossat MJ, Dao TP, Jenkins K, Dellarole M, Yang Y, McCallum SA, et al. Highresolution mapping of a repeat protein folding free energy landscape. Biophys $J$. 2016;111(11):2368-2376.

164. Ho BK, Gruswitz F. HOLLOW: generating accurate representations of channel and interior surfaces in molecular structures. BMC Struct Biol. 2008;6:49.

165. Royer CA. Revisiting volume changes in pressure-induced protein unfolding. Biochim Biophys Acta Protein Struct Mol Enzymol. 2002;1595(1-2):201-209.

166. Smeller L, Biology R, Smeller L. Pressure-temperature phase diagrams of biomolecules. Biochim Biophys Acta Protein Struct Mol Enzymol. 2002;1595 (1-2):11-29.

167. Font J, Benito A, Lange R, Ribo M, Vilanova M. The contribution of the residues from the main hydrophobic core of ribonuclease A to its pressure-folding transition state. Protein Sci. 2006;15(5):1000-1009.

168. Roche J, Caro JA, Norberto DR, Barthe P, Roumestand C, Schlessman JL, et al. Cavities determine the pressure unfolding of proteins. Proc Natl Acad Sci. 2012;109(18):6945-6950.

169. Ando N, Barstow B, Baase WA, Fields A, Matthews BW, Gruner SM. Structural and thermodynamic characterization of T4 lysozyme mutants and the contribution of internal cavities to pressure denaturation. Biochemistry. 2008;47(42):11097-11109. 
170. Chen CR, Makhatadze GI. Molecular determinant of the effects of hydrostatic pressure on protein folding stability. Nat Commun. 2017;8:14561.

171. Chen CR, Makhatadze GI. Molecular determinants of temperature dependence of protein volume change upon unfolding. J Phys Chem B. 2017;121(35):8300-8310.

172. Papini CM, Pandharipande PP, Royer CA, Makhatadze GI. Putting the piezolyte hypothesis under pressure. Biophys J. 2017;113(5):974-977.

173. Akasaka K. Probing conformational fluctuation of proteins by pressure perturbation. Chem Rev. 2006;106(5):1814-1835.

174. Akasaka K, Kitahara R, Kamatari YO. Exploring the folding energy landscape with pressure. Arch Biochem Biophys. 2013;531(1-2):110-115.

175. Jonas J. High-resolution nuclear magnetic resonance studies of proteins. Biochim Biophys Acta Protein Struct Mol Enzymol. 2002;1595(1-2):145-159.

176. Peng X, Jonas J, Silva JL. High-pressure NMR study of the dissociation of arc repressor. Biochemistry. 1994;33(27):8323-8329.

177. Li H, Yamada H, Akasaka K. Effect of pressure on individual hydrogen bonds in proteins. Basic pancreatic trypsin inhibitor. Biochemistry. 1998;37(5): 1167-1173.

178. Kremer W, Arnold MR, Brunner E, Schuler B, Jaenicke R, Kalbitzer HR. High pressure NMR spectroscopy and its application to the cold shock protein TmCsp derived from the hyperthermophilic bacterium Thermotoga maritima. In: Winter R, ed. Advances in High Pressure Bioscience and Biotechnology II, Proceedings. Springer, 2003, pp. 101-112.

179. Flynn PF, Milton MJ, Babu CR, Wand AJ. A simple and effective NMR cell for studies of encapsulated proteins dissolved in low viscosity solvents. J Biomol NMR. 2002;23(4):311-316.

180. Peterson RW, Nucci NV, Wand AJ. Modification of encapsulation pressure of reverse micelles in liquid ethane. J Magn Reson. 2011;212(1):229-233.

181. Fujisawa T, Kato M, Inoko Y. Structural characterization of lactate dehydrogenase dissociation under high pressure studied by synchrotron high-pressure small-angle X-ray scattering. Biochemistry. 1999;38(20):6411-6418.

182. Krywka C, Sternemann C, Paulus M, Javid N, Winter R, Al-Sawalmih A, et al. The small-angle and wide-angle X-ray scattering set-up at beamline BL9 of DELTA. J Synchrotron Radiat. 2007;14(3):244-251.

183. McCoy J, Hubbell WL. High-pressure EPR reveals conformational equilibria and volumetric properties of spin-labeled proteins. Proc Natl Acad Sci. 2011;108(4): 1331-1336.

184. Lerch MT, Horwitz J, McCoy J, Hubbell WL. Circular dichroism and site-directed spin labeling reveal structural and dynamical features of high-pressure states of myoglobin. Proc Natl Acad Sci. 2013;110(49):E4714-E4722.

185. Iwahashi H, Odani M, Ishidou E, Kitagawa E. Adaptation of Saccharomyces cerevisiae to high hydrostatic pressure causing growth inhibition. FEBS Lett. 2005;579(13):2847-2852.

186. Welch TJ, Farewell A, Neidhardt FC, Bartlett DH. Stress response of Escherichia coli to elevated hydrostatic pressure. J Bacteriol. 1993;175(22):7170-7177.

187. Aertsen A, Van Houdt R, Vanoirbeek K, Michiels CW. An SOS response induced by high pressure in Eschericia coli. J Bacteriol. 2004;186(18):6133-6141.

188. Fichtel K, Logemann J, Fichtel J, Rulkotter J, Cypionka H, Engelen B. Temperature and pressure adaptation of a sulfate reducer from the deep subsurface. Front Microbiol. 2015;6:1078. 
189. Ishii A, Sato T, Wachi M, Nagai K, Kato C. Effects of high hydrostatic pressure on bacterial cytoskeleton FtsZ polymers in vivo and in vitro. Microbiology. 2004; 150(Pt 6):1965-1972.

190. Aertsen A, Michiels CW. Mrr instigates the SOS response after high pressure stress in Escherichia coli. Mol Microbiol. 2005;58(5):1381-1391.

191. Aertsen A, Michiels CW. SulA-dependent hypersensitivity to high pressure and hyperfilamentation after high-pressure treatment of Escherichia coli lon mutants. Res Microbiol. 2005;156(2):233-237.

192. Bourges AC, Torres Montaguth OE, Ghosh A, Tadesse WM, Declerck N, Aertsen A, et al. High pressure activation of the Mrr restriction endonuclease in Escherichia coli involves tetramer dissociation. Nucleic Acids Res. 2017;45(9):5323-5332.

193. Salmon ED, Ellis GW. A new miniature chamber pressure for microscopy strain-free optical glass windows facilitate phase-contrast and polarized-light microscopy of living cells. J Cell Biol. 1975;65:587-602.

194. Crenshaw HC, Salmon ED. Hydrostatic pressure to 400 atm does not induce changes in the cytosolic concentration of $\mathrm{Ca}^{2+}$ in mouse fibroblasts: measurements using fura2 fluorescence. Exp Cell Res. 1996;227(2):277-284.

195. Müller JD, Gratton E. High-pressure fluorescence correlation spectroscopy. Biophys J. 2003;85(4):2711-2719.

196. Nishiyama M, Kojima S. Bacterial motility measured by a miniature chamber for high-pressure microscopy. Int J Mol Sci. 2012;13(7):9225-9239.

197. Koo J, Czeslik C. High pressure sample cell for total internal reflection fluorescence spectroscopy at pressures up to 2500 bar. Rev Sci Instrum. 2012;83(8):085109.

198. Frey B, Hartmann M, Herrmann M, Meyer-Pittroff R, Sommer K, Bluemelhuber G. Microscopy under pressure - an optical chamber system for fluorescence microscopic analysis of living cells under high hydrostatic pressure. Microsc Res Tech. 2006;69(2):65-72. 